E-ISSN : 2549-6581

Artikel Hasil Penelitian

OPEN ACCESS

Diterima : 16 Juni 2019

Direview : 4 Juli 2019

Dimuat : April 2019 - Juli 2019 Midwifer

\title{
Pengaruh Ekstrak Etanol Brokoli Terhadap Histologi Tuba Fallopi Tikus Putih yang Dipapar MSG
}

\author{
Onnitia D.P.C ${ }^{\left.1^{*}\right)}$, Nurdiana ${ }^{2}$, Ni Luh Putu Herli Mastuti ${ }^{3}$ \\ ${ }^{1 *}$ Program Studi S1 Kebidanan, Fakultas Kedokteran, Universitas Brawijaya, Email: \\ onnitia.dpc@gmail.com, TIp: +6285771700308 \\ ${ }^{2}$ Laboratorium Farmakologi Fakultas, Fakultas Kedokteran, Universitas Brawijaya, Email: \\ farmakodes@gmail.com \\ ${ }^{1}$ Program Studi S1 Kebidanan, Fakultas Kedokteran, Universitas Brawijaya, Email: \\ niluhputuherlimastuti@gmail.com
}

\begin{abstract}
Background: the habit of consuming fast food in Indonesia reaches 69\%/day. MSG can endanger health, especially female reproductive organs it can cause infertility. Objective: to prove the effect of broccoli ethanol extract in increasing total secretory epithelial cells and thickness of fallopian tube smooth muscle exposed to MSG. Method: this design is Randomized Post Test Only by comparing the variables studied between treatment groups. The group was divided into 5 namely: $K(-)$ not given MSG exposure and broccoli ethanol extract; $K(+)$ given MSG exposure of $0.7 \mathrm{mg} / \mathrm{gBB}$; $P 1$ (MSG $0.7 \mathrm{mg} / \mathrm{gBB}+500$ $\mathrm{mg} / \mathrm{kgBB}$ of broccoli ethanol extract); P2 (MSG $0.7 \mathrm{mg} / \mathrm{gBB}+1000 \mathrm{mg} / \mathrm{kgBB}$ of broccoli ethanol extract); P3 (MSG $0.7 \mathrm{mg} / \mathrm{gBB}+2000 \mathrm{mg} / \mathrm{kgBB}$ of broccoli ethanol extract). Provision of treatment carried out for 28 days. The termination was carried out on day 29 when the rat was in the proestrus phase, then the HE was stained to find out the histopathological picture of the fallopian tube of the mouse then observed under a microscope. Results: ANOVA test on mean secretory epithelial cells produced a significant difference $(p=0,000$ or $<0.05)$, while the HSD test results proved that not all treatment groups obtained significant differences. The amount of thick muscle layer shows that there is no significant difference. Conclusion: Broccoli ethanol extract was able to increase the mean of secretory epithelial cells and the thickness of the smooth muscle layer of the fallopian tubes exposed to MSG, although there were no significant differences between groups.
\end{abstract}

Keywords: MSG, Broccoli Extract, Fallopian tube.

\begin{abstract}
ABSTRAK
Latar belakang: kebiasaan mengkonsumsi makanan cepat saji di Indonesia mencapai $69 \% /$ hari. MSG dapat membahayakan kesehatan, terutama organ reproduksi wanita yang dapat menyebabkan infertilitas. Tujuan: membuktikan adanya pengaruh ekstrak etanol brokoli dalam peningkatan total sel epitel sekretorik dan ketebalan otot polos tuba fallopi yang terpapar MSG. Metode: rancangan penelitian ini yaitu Randomized Post Test Only
\end{abstract}


dengan membandingkan variabel yang diteliti antar kelompok perlakuan. Kelompok dibagi menjadi 5 yaitu: $\mathrm{K}(-)$ tidak diberi paparan MSG dan ekstrak etanol brokoli; $\mathrm{K}(+)$ diberi paparan MSG 0,7 mg/gBB; P1 (MSG 0,7 mg/gBB +500 mg/kgBB ekstrak etanol brokoli); P2 (MSG 0,7 mg/gBB+1000 mg/kgBB ekstrak etanol brokoli); P3 (MSG 0,7 mg/gBB+2000 $\mathrm{mg} / \mathrm{kgBB}$ ekstrak etanol brokoli). Pemberian perlakuan dilakukan selama 28 hari. Terminasi dilakukan di hari ke 29 saat tikus dalam fase proestrus, selanjutnya dilakukan pengecatan HE untuk mengetahui gambaran histopatologi tuba fallopi tikus kemudian diamati dengan mikroskop. Hasil: uji ANOVA pada rerata sel epitel sekretorik menghasilkan perbedaan yang bermakna $(p=0,000$ atau $<0,05)$, sedangkan hasil uji HSD membuktikan tidak semua kelompok perlakuan diperoleh perbedaan yang signifikan.Pada jumlah tebal lapisan otot polos menunjukkan bahwa tidak terdapat perbedaan yang bermakna. Simpulan: ekstrak etanol brokoli mampu meningkatkan rerata sel epitel sekretorik dan tebal lapisan otot polos tuba fallopi yang dipapar MSG, meskipun tidak diperoleh perbedaan yang signifikan antar kelompok.

Kata kunci: MSG, Ekstrak brokoli, tuba fallopi.

*Korespondensi:NamaPenulis. Surel: onnitia.dpc@gmail.com

\section{PENDAHULUAN}

Masyarakat kota di Indonesia yang mengkonsumsi makanan cepat saji mencapai 69\%. Pola konsumsi makanan yang banyak mengandung bahan penyedap, pengawet dan pemanis dapat menimbulkan efek buruk bagi tubuh ${ }^{1}$. Contohnya pada konsumsi Monosodium Glutamat (MSG) yang berlebihan dapat mempengaruhi kesehatan organ reproduksi pada wanita. Sebuah penelitian menyatakan bahwa semakin tinggi dosis MSG yang diberikan pada tikus secara terus-menerus dapat mengakibatkan perubahan degeratif dan atrofi pada ovarium².

Monosodium Glutamat menyebabkan kerusakan nukleus arkuata hipotalamus, sehingga dapat menurunkan sekresi thyrotropin, kortikotropin, FSH dan LH.Konsumsi MSG di Indonesia mencapai 0,6 gram/hari, dan di Eropa rata-rata masyarakatnya mengkonsumsi MSG sebesar 5-12 gram/hari ${ }^{3}$. Sedangkan batas aman dalam mengkonsumsi MSG per harinya yaitu 0,5-2,5 gram 4 .

Pemberian MSG pada tikus betina dewasa strain wistar dengan dosis 0,7 $\mathrm{mg} / \mathrm{gBB}$ selama 42 hari dapat terjadipenipisan otot polos danpenurunan sel epitel sekretorik tuba fallopi ${ }^{5}$.Fungsi tuba fallopi yaitu menangkap ovum saat terjadi ovulasi dan mengantarkannya untuk bertemu sperma. Hal ini didukung oleh kerja otot polos, totalsel epitel sekretorik dan bersilia. Apabila terjadi gangguan pada tuba fallopi maka dapat menyebabkan infertilitas ${ }^{6}$.

Antioksidan sangat diperlukan untuk menetralisir radikal bebas didalam tubuh, yang berupa glutation perioksidase, vitamin $(A, C, E), \quad \beta$ karoten, flavonoid,dll.Senyawa flavonoid merupakan inhibitor yang kuat dalam menangkap senyawa oksigen atau nitrogen (ROS atau RNS) dan menghambat kerusakan hem protein, serta peningkatan ion logam. Hal ini ditunjukkan dengan nilai kadar flavonoid total dalam ekstrak brokoli dengan menggunakan metode maserasi yaitu $43,67 \mu \mathrm{g} / \mathrm{ml}$ dan nilai $\mathrm{IC}_{50}$ sebesar $3,63 \mu \mathrm{g} / \mathrm{ml}^{7}$.

\section{METODE PENELITIAN}

Rancangan penelitian ini menggunakan Randomized Post Test Only. Tikus yang digunakan jenis 
(Rattus novergicus) wistar betina dengan usia 4-12 minggu, memiliki berat 150-200gr, dan kondisinya sehat. Tikus yang digunakan berjumlah 30 ekor, yang akan terbagi dalam 5 kelompok, dimana tiap kelompok ada 6 tikus. Kelompok kontrol negatif (K-) tidak diberi MSG dan ekstrak etanol brokoli; kelompok kontrol positif $(\mathrm{K}+)$ diberi paparan MSG namun tidak diberi ekstrak etanol brokoli; kelompok perlakuan $(1,2,3)$ dipapar MSG dan diberi ekstrak etanol brokoli dengan dosis berbeda yaitu masing-masing $500 \mathrm{mg} / \mathrm{kgBB}, 1000$ $\mathrm{mg} / \mathrm{kgBB}$ dan $2000 \mathrm{mg} / \mathrm{kgBB}$.

Ekstrak etanol brokoli dan MSG akan dilarutkan dengan aquades, dimana akan diambil masing-masing 1 cc dan akan diberikan secara per oral, selama 28 hari. Pada hari ke 29 , akan dilakukan swab vagina untuk mengetahui fase proestrus tikus. Jika tikus tidak dalam fase proestrus maka tetap dilanjutkan pemberian perlakuan, sedangkan tikus yang dalam fase proestrus akan dilakukan pembedahan untuk mengambil organ tuba fallopi. Kemudian dilakukan pemeriksaan histopatologi dengan pengecatan Hematoksilin dan Eosin. Pengamatan histopatologi menggunakan software OlyVIA dan Dot Slide Microscope Olympus BX51 dengan 5 lapang pandang jumlah sel epitel sekretorik dan 10 titik tebal lapisan otot polos tuba fallopi.

Analisis data menggunakan uji normalitas (uji Shapiro Wilk); uji homogenitas (uji Leuvene's); uji ANOVA; dan uji HSD.

\section{HASIL PENELITIAN}

Hasil penelitian jumlah sel epitel sekretorik pada uji normalitas menggunakan Shapiro Wilk, menunjukkan bahwa nilai $p=0,374$ $(p>0,05)$ berarti signifikan. Hal tersebut membuktikan data terdistribusi normal. Uji homogenitas menggunakan Leuvene'smenunjukkan nilai $\mathrm{p}$-value $=$ $0,525$ ( $p>0,05)$, artinya signifikan. Kesimpulan dari uji tersebut didapatkan data homogen. Syarat ANOVAOne Waytelah terpenuhi, selanjutnya akan dilakukan analisis data.

Uji ANOVAOne Way dilakukan untuk mengukur rata-rata variabel yang diteliti disetiap kelompok kontrol maupun perlakuan.

Tabel 1. Perbandingan rerata total sel epitel sekretorik tuba fallopi antar kelompok

\begin{tabular}{|c|c|c|}
\hline Kelompok Subyek Pengamatan & Mean \pm SD (sel) & $p$-value \\
\hline Kontrol negatif & $50,70 \pm 7,81^{b}$ & \multirow{5}{*}{$0,000<a$} \\
\hline Kontrol positif (MSG 0,7 mg/gBB) & $27,76 \pm 3,75^{a}$ & \\
\hline P1 (MSG+eks.brokoli $500 \mathrm{mg} / \mathrm{kgBB}$ ) & $45,66 \pm 5,81^{b}$ & \\
\hline P2 (MSG+eks. brokoli $1000 \mathrm{mg} / \mathrm{kgBB}$ ) & $66,80 \pm 4,20^{\circ}$ & \\
\hline P3 (MSG+eks. brokoli $2000 \mathrm{mg} / \mathrm{kgBB}$ ) & $53,47 \pm 6,59^{\circ}$ & \\
\hline
\end{tabular}

Hasil uji One Way ANOVAdiperoleh nilai $\mathrm{p}=0,000$ yang menunjukkan ada pengaruh signifikan pada pemberian ekstrak etanol brokoli terhadap peningkatan rerata total sel epitel sekretorik tuba fallopi (Tabel 1). Untuk melihat perbedaan disetiap kelompok, maka perlu melakukan uji HSD.

\section{Tabel 2. Uji HSD perhitungan sel epitel sekretorik}

\begin{tabular}{|c|c|c|}
\hline \multicolumn{2}{|c|}{ Perbandingan } & p-value \\
\hline \multirow{4}{*}{$\begin{array}{l}\text { Kontrol } \\
\text { negatif }\end{array}$} & Kontrol positif & $0,000^{*}$ \\
\hline & $\mathrm{P} 1$ & 0,713 \\
\hline & $\mathrm{P} 2$ & $0,000^{*}$ \\
\hline & P3 & $0,004^{*}$ \\
\hline \multirow{3}{*}{$\begin{array}{l}\text { Kontrol } \\
\text { positif }\end{array}$} & P1 & $0,001^{*}$ \\
\hline & P2 & $0,000^{*}$ \\
\hline & P3 & $0,000^{*}$ \\
\hline \multirow{2}{*}{ P1 } & $\mathrm{P} 2$ & $0,000^{*}$ \\
\hline & P3 & $0,000^{*}$ \\
\hline $\mathrm{P} 2$ & P3 & 0,142 \\
\hline
\end{tabular}

Keterangan: * : berbeda signifikan $(p<0,05)$ 
Apabiladilakukan perbandingan antara $\mathrm{K}(-)$ dan $\mathrm{K}(+)$ didapatkan $p<0,05$, yang berarti pemaparan MSG berdampak pada penurunan jumlah sel epitel sekretorik secara signifikan. Apabila $\mathrm{K}(+)$ dibandingkan dengan kelompok perlakuan (P1,P2 dan P3), juga didapatkan perbedaan yang signifikan. Hal ini berarti pemberian ekstrak etanol brokoli dalam berbagai dosis mampu meningkatkan jumlah sel epitel sekretorik secara signifikan. Hasil pengujian ini menunjukkan bahwa pemberian ekstrak etanol brokoli dengan perlakuanP2 (1000 $\mathrm{mg} / \mathrm{kgBB}$ ) mampu meningkatkan jumlah sel epitel sekretorik tuba fallopi tikus yang dipapar MSG $(0,7 \mathrm{mg} / \mathrm{gBB})$ karena rata-rata sel epitel sekretorik pada perlakuan P2 lebih tinggi dibandingkan kontrol negatif.

Hasil penelitian tebal lapisan otot polos tuba fallopi pada uji normalitas menggunakan Shapiro Wilk, menunjukkan bahwa nilai $p=0,973$ atau $p>0,05$ berarti signifikan. Hal tersebut membuktikan data terdistribusi normal. Uji homogenitas menggunakan Leuvene'smenunjukkan nilai $p$-value $=0,162$, menunjukkan hasil signifikan karena $p>0,05$. Simpulan uji ini membuktikan data homogen.

\section{Tabel 3. Perbedaan rerata ketebalan lapisan otot polos tuba fallopi}

\begin{tabular}{|c|c|c|}
\hline Kelompok Subyek Pengamatan & Mean $\pm \mathrm{SD}(\mu \mathrm{m})$ & p-value \\
\hline Kontrol negatif & $281,67 \pm 71,89$ & \multirow{5}{*}{$0,306<c$} \\
\hline Kontrol positif (MSG 0,7 mg/gBB) & $238,41 \pm 17,00$ & \\
\hline $\begin{array}{l}\text { P1 (MSG+eks. brokoli } 500 \\
\mathrm{mg} / \mathrm{kgBB} \text { ) }\end{array}$ & $301,06 \pm 86,08$ & \\
\hline $\begin{array}{l}\text { P2 (MSG+eks. brokoli } 1000 \\
\mathrm{mg} / \mathrm{kgBB} \text { ) }\end{array}$ & $333,17 \pm 116,63$ & \\
\hline $\begin{array}{l}\text { P3 (MSG+eks. brokoli } 2000 \\
\mathrm{mg} / \mathrm{kgBB} \text { ) }\end{array}$ & $309,06 \pm 56,47$ & \\
\hline
\end{tabular}

Hasil uji One Way ANOVAmenghasilkan nilai $\mathrm{p}=0,306$ yaitu tidak diperoleh pengaruh yang signifikan pada pemberian ekstrak etanol brokoli terhadap peningkatan rerata jumlah sel epitel sekretorik tuba fallopi (Tabel 3).

\section{PEMBAHASAN}

Berdasarkan hasil dari analisa data membuktikan bahwa pada kelompok $\mathrm{K}(+)$ yang diberi paparan MSG mampu menurunkan fungsi dari tuba fallopi. Hal tersebut dapat terjadi disebabkan adanya peningkatan Reactive Oxygen Species (ROS) didalam tubuh, yang disebabkan oleh tingginya kadar glutamat dalam plasma. Peningkatan kadar glutamat terjadi karena pemberian MSG yang berlebihan. Peningkatan kadar ROS dalam tubuh dapat menyebabkan terganggunya kerja hipofise anterior dalam merangsang sekresi FSH dan LH. Jika sekresi hormon tersebut terganggu, maka sekresi progesteron dan estrogen pada ovarium juga terganggu. Sedangkan hormonhormon tersebut memiliki peran penting dalam siklus reproduksi. Hasil penelitian ini sejalan dengan penelitian yang dilakukan oleh Umami (2014), yaitu dengan pemberian MSG dosis $0,7 \mathrm{mg} / \mathrm{gBB}$ secara oral selama 42 hari dapat menyebabkan penurunan histologi tuba fallopi secara signifikan.

Sel epitel sekretorik merupakan sel tanpa silia yang banyak mensekresi cairan yang mengandung karbohidrat (galaktosa) dan enzim yang bersifat nutritif untuk sperma, embrio dan melubrikasi jalan embrio menuju uterus selama berada di tuba fallopi. Selain itu, sel epitel sekretorik juga dapat memberikan kapasitasi sperma yang berkaitan dengan sel silia tuba untuk bergerak hiperaktif dan memberikan waktu yang lebih cepat untuk reaksi akrosom. Sel epitel sekretorik akan bekerja secara optimal 
pada saat ovulasi, dimana hal tersebut sangat bergantung pada kadar estrogen. Beberapa penelitian mengungkapkan bahwa penurunan jumlah sel epitel sekretorik dapat memicu terjadinya radang panggul, dimana keadaan tersebut merupakan salah satu penyebab infertilitas ${ }^{8}$.

Lapisan otot polos tuba fallopi terbagi menjadi dua lapisan: longitudinal dan sirkuler. Dimana lapisan tersebut akan semakin menebal pada bagian isthmus dan akan menghasilkan gerakan peristaltik untuk membantu dalam memindahkan sel telur ke uterus. Gerakan peristaltik tersebut dipengaruhi oleh hormon estrogen-progesteron, hormon prostaglandin dan sistem adrenergik. Ketiga hormon tersebut memiliki peranan yang berbeda.Dimana estrogen akan merangsang motilitas tuba, sedangkan prostaglandin akan meregulasi motilitas tuba secara spontan dan sistem adrenergik berperan dalam mengaktivasi estrogen sehingga dapat terjadi pembuahan dengan baik ${ }^{9}$. Penelitian lain mengatakan bahwa sistem saraf simpatis berfungsi mengatur otot polos dalam merespon estrogen dan progesteron. Apabila terjadi penurunan kadar estrogen yang disebabkan oleh radikal bebas dalam tubuh, maka dapat menyebabkan motalitas tuba menjadi terganggu atau menurun ${ }^{10}$.

Maka dari itu dengan memberikan antioksidan dari ekstrak etanol brokoli diharapkan mampu untuk mengurangi radikal bebas yang disebabkan oleh glutamat. Brokoli memiliki kadar flavonoid tinggi dengan aktivitas antioksidan tinggi pula yang ditunjukkan dengan $\mathrm{IC}_{50}$ sebesar 8,36 $\mu \mathrm{g} / \mathrm{ml}$. Kandungan flavonoid dari brokoli mampu mencegah oksidasi sel, lipid dan DNA oleh radikal bebas, serta mampu menghambat sitokrom P450 dan meningkatkan kadar glutation.Mekanisme flavonoid dalam menangkal radikal bebas yaitu dengan mendonorkan satu atom hidrogen menjadi molekul yang stabil ${ }^{11}$. Beberapa penelitian menyebutkan bahwa ekstrak etanol brokoli mampu menurunkan derajat sel busa pada gambaran histopatologi aorta tikus wistar hiperlipidemia ${ }^{12}$.

\section{SIMPULAN}

Ekstrak etanol brokoli dosis (500, 1000 dan 2000) mg/kgBB mampu menaikkan rerata total sel epitel sekretorik secara bermakna, akan tetapi pada ketebalan lapisan otot polos tuba fallopi tikus wistar yang diberi MSG tidak terdapat perbedaan yang berarti setiap kelompok perlakuan. Pada penelitian selanjutnya, disarankan untuk melakukan penelitian lebih lanjut terkait uji toksisitas ekstrak etanol brokoli untuk mengetahui dosis toksik pada ekstrak etanol brokoli.

\section{DAFTAR PUSTAKA}

1. Lestari, S. 2011. Faktor Resiko Penyebab Kejadian Obesitas pada MahasiswaFakultas Kedokteran Universitas Sumatera Utara. Tesis FKM USU.

2. Eweka, O.A., Iniabohs. 2011. Histological Studies of the Effectof Monosodium Glutamate on the Ovaries of Adult Wistar Rats. Annals of Medica and Health Science Research. 1 (1): 37-44.

3. Beyreuther, K., HK Blesalski, JD Fernstrom, P Grimm, WP Hammes, U Heinemann, et al. 2006. Consensus Meeting: 
Monosodium Glutamate - an update. EJCN, 1-10.

4. Food and Drug Administration. 2012. Questions And Answer On Monosodium Glutamate (MSG). Report From The Agencies No.265.

www.ncbi.nlm.nih.gov/pmc/articles /PMC3649108/

5. Umami, Riza, Pande Made Dwijayasa, and Sri Winarsih. 2014. Pengaruh Vitamin C dan E terhadap Histologi Tuba Fallopii pada Tikus yang Dipapar MSG. Jurnal Kedokteran Brawijaya 28.2, 63-67.

6. Lyons AR, Saridogan E, and Djahanbakhch O. 2006. The Reproductive Significance of Human Fallopian Tube Cilia. Human Reproductive Updates. 7 (1): 363-372.

7. Lutfina DR. 2012. Pengaruh Perbedaan Metode Ekstraksi Terhadap Kandungan Flavonoid Total dan Aktivitas Antioksidan Brokoli (Brassica oleracea L. CV. Group Broccoli). Skripsi. Diterbitkan, Fakultas MIPA Universitas Islam, Bandung.

8. El-Mowafi, D. M. 2012. Fallopian Tube. Reproductive Endocrinology and Infertility. Wayne State University, United Stated America. (Online)

www.gfmer.ch/International_activiti es_En/El_Mowafi/Fallopian_tube.h tm

9. Bylander, A. 2014. Progesterone's Effect on Gamete Transport in The Fallopian Tube. Disertasi. Department of infectious diseases institute of biomedicine Sahlgrenska Academy at the University of Gothenburg, Sweden.

10. Talbot, P., Riveles, K. 2005. Smoking and Reproduction: The Oviduct as a Target of Cigarette Smoke. Reproductive Biology and
Endocrinology. BioMed Central. 3(52): 1-17.

11. Wardani, Rizka Nuzula, Elly Nurus Sakinah, and Yudha Nurdian. 2016. Pengaruh Pemberian Ekstrak Etanol Brokoli (Brassica oleracea) terhadap Kadar SGOT dan SGPT Tikus Wistar yang Diinduksi DMBA (The Effect of Ethanolic Extract of Broccoli (Brassica oleracea) on SGOT and SGPT of Wistar Rats Induced by DMBA). Pustaka Kesehatan 4.2, 196-199.

12. Vania, D., Basyar, E., \& Soeharti, C. 2019. Pengaruh Pemberian Ekstrak Brokoli (Brassica Oleracea L. Var Italica) Terhadap Histopatologi Aorta Tikus Wistar Hiperlipidemia. Jurnal Kedokteran Diponegoro. 8(1), 121-132. 